\title{
DIFFERENTIAL AGGLUTINATION TITRE (D.A.T.) IN JUVENILE RHEUMATOID ARTHRITIS
}

\author{
BY \\ E. G. L. BYWATERS, MARY E. CARTER, AND F. E. T. SCOTT \\ From the Rheumatism Research Unit, Medical Research Council, \\ Canadian Red Cross Memorial Hospital, Taplow
}

This study concerns the titre of differential sheep cell agglutination (Rose-Waaler) in rheumatoid arthritis affecting children, its variability and its correlation with other clinical features, during a period of at least 4 years' observation.

\section{Method}

The technique employed from 1949-1956, which has been described by one of us (Scott, 1952), was a slight modification of the method originally proposed by Rose, Ragan, Pearce, and Lipman (1948). Since 1956, a further modification has been employed, as suggested by Greenbury (1957), using Perspex trays (M.R.C. pattern) in place of tubes and racks. This method will be described in detail elsewhere (Bywaters and Scott, unpublished). The results by the two methods are closely comparable, the newer method giving more consistent results.

The results are expressed as a differential titre (ratio) in both methods, and the lowest ratio accepted as positive in a series of doubling dilutions is $1: 16$. Slight changes in the sensitivity of the method have been found to occur because of variations in agglutinability of red cell suspensions from different sheep, amounting usually to not more than a one-tube difference. A single positive result occurring in the midst of a series of negative tests in one individual is therefore suspect and may well be due to technical factors, although in an attempt to control this, sera of known titre were included as a safeguard in each series of titrations.

\section{Material}

This series consists of 142 patients ( 85 females and 57 males) admitted to this Unit from its inception in 1947 to the end of 1953, and followed to December 31, 1957, giving, for the purpose of this study, a maximum follow- up period of 10 years and a minimum of 4 years; since the D.A.T. test was not started here until January, 1949, the period of D.A.T. observation ranges from 4 to 8 years in all cases, except in two patients who died and were followed for 3 years only. The 142 cases were all under 16 years of age at the onset of their illness.

75 patients were first seen more than one year after the onset of disease (referred to as "late" cases) and 67 within one year of onset ("early" cases). Patients were seen after discharge as a rule at least yearly when blood was taken. The mean number of D.A.T.s done per patient in this study was $9 \cdot 5$ (ranging from 2 to 24 ).

The diagnostic criteria for admission to the series were as follows:

(i) Polyarthritis affecting four or more joints, past or present, other diagnoses having been excluded.

(ii) Less than four joints involved, but diagnosis confirmed by synovial biopsy. Four patients had three joints involved, six had two joints involved, and three had one joint involved. Twelve of these thirteen patients had biopsy confirmation; the thirteenth was a child with monarthritis who also had iritis and had been followed for 8 years.

These criteria included five patients with psoriasis, (four with negative D.A.T.S and one with one D.A.T. at $1: 32$ ), one patient with ulcerative colitis, and one with sacro-iliac involvement.

Disease activity was considered to be present if there was active joint involvement with two out of the four following:

(1) Joint pain.

(2) Joint warmth.

(3) Joint limitation of movement.

(4) Joint swelling. 
Table I shows the results taking all D.A.T.s done (Groups I-III) and Table II the results of only the first D.A.T. done (Groups IV and V). The distribution of sex within these groups and the mean duration of follow-up are also shown. The difference between the mean duration of follow-up of Group I "all negative" (5.2 yrs) and of Group III "two or more positive" $(6 \cdot 1 \mathrm{yrs})$ is statistically significant $(p=<0.01)$, but this does not affect the conclusions drawn from subsequent Tables. The only possible inference is that a slightly greater number of patients might become sero-positive if followed for longer periods.

The intermediate Group II of 36 patients with only one positive D.A.T. (Table I) we have found to resemble more closely the negative group as regards age and sex incidence (see Tables III and IV), whether the lone positive result was $1: 16$ (21 cases) or $1: 32$ or more (15 cases); 32 out of the 36 had between six and 21 estimations made, the remaining four having two, three, four, and four respectively Altogether, in these 36 patients, the single positive result represented in most cases under 20 per cent $\stackrel{\oplus}{\stackrel{9}{9}}$ of all D.A.T.s done, whereas in the 28 cases withe more than one positive result, the positive results represent 60 per cent. of all D.A.T.s done. We feef that some of these single positive results in the mids 8 of a negative series might possibly be due to technicans error.

Age Incidence.-Table III (opposite) shows that the proportion of cases in which the first D.A.T. wase positive increased markedly with age at onset. similar relationship to age at onset is seen in the posi tive cases (Group III), but not in the negative case ${ }_{\omega}^{\infty}$ (Group I) or in the doubtful positive cases (Groupd II), although the difference between the positive and

TABLE I

RESULTS OF ALL TESTS DONE IN 142 CASES, BY SEX, MEAN DURATION OF FOLLOW-UP, AND MEAN DURATION FROM ONSET TO TIME FIRST EXAMINED

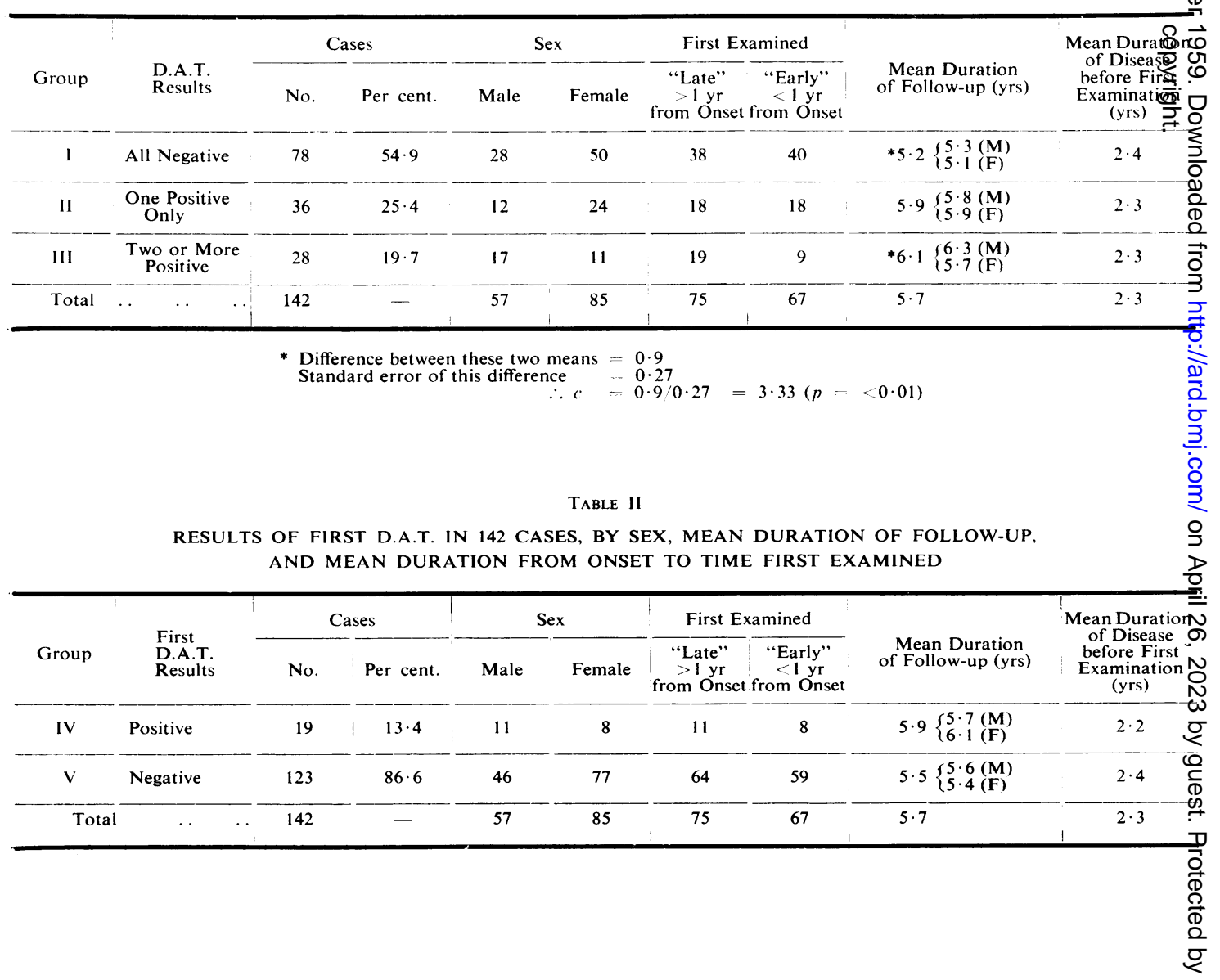


TABLE III

AGE INCIDENCE

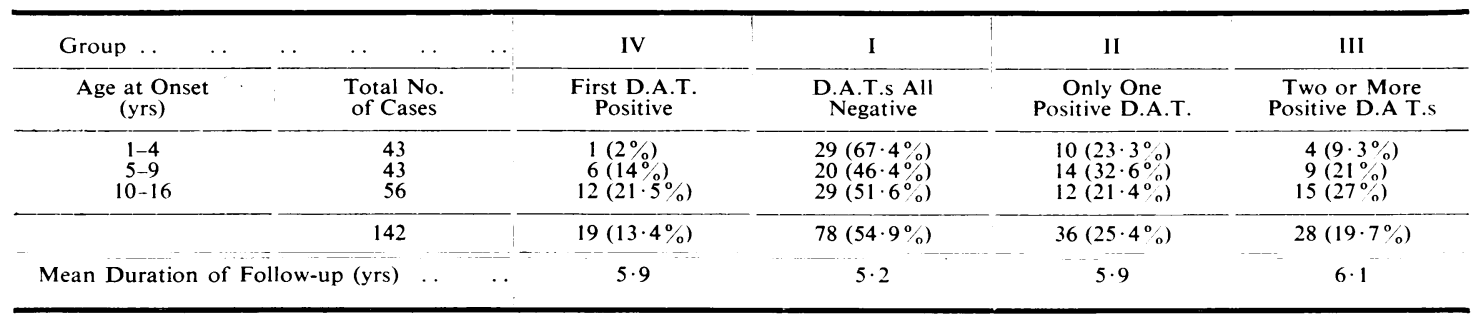

negative groups is just not significant $(0 \cdot 1>$ $p>0.05)$ at the 5 per cent. level. Table III also shows the mean duration of follow-up for each of the groups. The positive cases (Group III) were followed slightly longer than the all-negative cases (Group I), which may have exposed them to a slightly greater risk of giving a positive result, but this would not have influenced those whose first D.A.T. was positive (Group IV), who were followed as long as the more highly-positive group and who also showed a tendency for more positive results in the older age groups.

Table IIIA shows the mean duration of follow-up

TABLE IIIA

AGE INCIDENCE AND MEAN DURATION OF DISEASE AND LENGTH OF FOLLOW-UP IN THREE GROUPS

\begin{tabular}{cccc}
\hline $\begin{array}{c}\text { Age at } \\
\text { Onset } \\
\text { (yrs) }\end{array}$ & $\begin{array}{c}\text { Total } \\
\text { No. of } \\
\text { Cases }\end{array}$ & $\begin{array}{c}\text { Mean Duration } \\
\text { of Follow-up } \\
\text { (yrs) }\end{array}$ & $\begin{array}{c}\text { Mean Duration } \\
\text { of Disease from } \\
\text { Onset to End } \\
\text { of Follow-up } \\
\text { (yrs) }\end{array}$ \\
\hline $1-4$ & 43 & $5 \cdot 5$ & $\begin{array}{c}9 \cdot 2 \\
5-9\end{array}$ \\
$10-16$ & 43 & $5 \cdot 8$ & $7 \cdot 7$ \\
\hline
\end{tabular}

for each of the three age groups, 1-4, 5-9, and 10-16 yrs, and the mean duration of disease from onset. The oldest group, which was most frequently positive, was followed for a slightly shorter period than the younger groups, so that the significance of the trend for positives to occur in the older group is not altered by length of follow-up, nor by the duration of disease.

Sex Incidence.- - In Table IV the observed numbers of positive and negative cases in each of the various groups have been compared with the expected numbers on the nul hypothesis, and the $\chi^{2}$ values calculated.

The proportion of males to females is the same in Groups I and II, but in Groups IV and III males are more frequently D.A.T.-positive than females, although this only approaches statistical significance in Group III ( $\chi^{2}$, Yates' modification =$3.36 ; 0.1>p>0.05)$. Although the males were followed for 5.8 years (mean) and the females for $5 \cdot 5$ years (mean), this does not alter the conclusions stated above, as in Group III both sexes fell into the longest follow-up period (mean $6 \cdot 1 \mathrm{yrs}$ ).

TABLE IV

SEX INCIDENCE

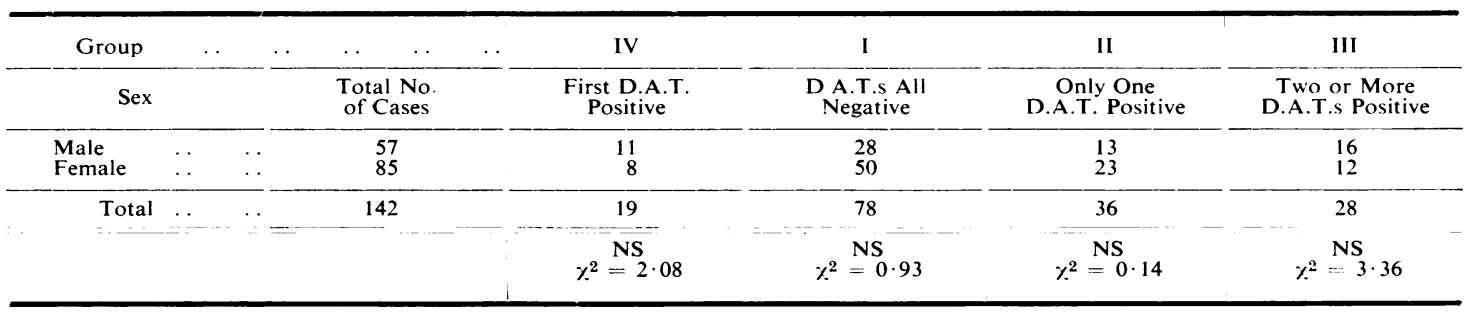


Variation of D.A.T. during Course of Disease.This has been examined for each 2-year period of observation, in respect both of tests (Table V) and of persons (Table VI), in the group of 64 children with at least one positive D.A.T. during observation. Tables VA and VIA show the total series of 142 cases.
These four Tables show a tendency for the D.A.T to become negative with duration of disease. This tendency was slightly more marked in the earlyen. cases. In both early and late cases some initially positive changed to negative and vice versa. Onlyes nine of the 64 patients showed at least one positive result each year.

TABLE V

PROPORTION OF POSITIVE D.A.T.S TO TOTAL NUMBER DONE IN 2-YEAR PERIODS ON 64 PATIENTS WITH AT LEAST ONE POSITIVE D.A.T. DURING OBSERVATION

\begin{tabular}{|c|c|c|c|c|c|c|c|c|c|c|}
\hline \multirow{3}{*}{ First Examined } & \multirow{3}{*}{$\begin{array}{l}\text { No. } \\
\text { of } \\
\text { Cases }\end{array}$} & \multicolumn{8}{|c|}{ Years of Observation } & \multirow{3}{*}{$\begin{array}{l}\text { Total D.A.T.s } \\
\text { Done on } \\
64 \text { Patients }\end{array}$} \\
\hline & & \multicolumn{2}{|c|}{ 1st and 2 nd } & \multicolumn{2}{|c|}{3 rd and 4 th } & \multicolumn{2}{|c|}{5 th and 6 th } & \multicolumn{2}{|c|}{7 th and 8 th } & \\
\hline & & No. & Per cent. & No. & Per cent. & No. & Per cent. & No. & Per cent. & \\
\hline Early & 27 & $38 / 175$ & $21 \cdot 7$ & $13 / 78$ & $16 \cdot 7$ & $5 / 44$ & $11 \cdot 4$ & $1 / 21$ & $4 \cdot 8$ & 318 \\
\hline Late & 37 & $60 / 185$ & $32 \cdot 4$ & $32 / 105$ & $30 \cdot 5$ & $22 / 86$ & $25 \cdot 6$ & $6 / 40$ & 15 & 416 \\
\hline Total & 64 & $98 / 360$ & $27 \cdot 2$ & $45 / 183$ & $24 \cdot 6$ & $27 / 130$ & $20 \cdot 8$ & $7 / 61$ & $11 \cdot 5$ & 734 \\
\hline
\end{tabular}

TABLE $\mathrm{VA}_{\text {A }}$

PROPORTION OF POSITIVE D.A.T.S TO TOTAL NUMBER DONE IN 2-YEAR PERIODS IN THE TOTAL SERIES OF 142 PATIENTS

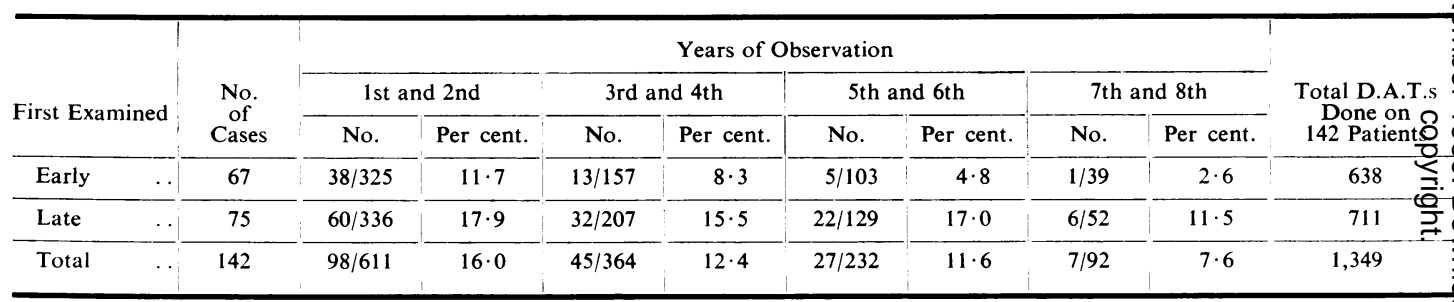

TABLE VI

PROPORTION OF PATIENTS WITH A POSITIVE D.A.T. IN EACH 2-YEAR PERIOD TO NUMBER OF PATIENTS TESTED AT LEAST ONCE IN EACH 2-YEAR PERIOD

\begin{tabular}{|c|c|c|c|c|c|c|c|c|c|c|}
\hline \multirow{3}{*}{\multicolumn{2}{|c|}{$\begin{array}{c}\text { First } \\
\text { Examined }\end{array}$}} & \multirow{3}{*}{$\begin{array}{c}\text { No. } \\
\text { of } \\
\text { Cases }\end{array}$} & \multicolumn{8}{|c|}{ Years of Observation } \\
\hline & & & \multicolumn{2}{|c|}{1 st and 2 nd } & \multicolumn{2}{|c|}{3 rd and 4 th } & \multicolumn{2}{|c|}{5 th and 6 th } & \multicolumn{2}{|c|}{7 th and 8 th } \\
\hline & & & No. & Per cent. & No. & Per cent. & No. & Per cent. & No. & Per cent. \\
\hline Early & $\cdots$ & 27 & $20 / 27$ & $74 \cdot 1$ & $7 / 25$ & 28 & $5 / 21$ & $23 \cdot 8$ & $1 / 9$ & $11 \cdot 1$ \\
\hline Late & .. & 37 & $19 / 37$ & $51 \cdot 2$ & $20 / 34$ & $58 \cdot 8$ & $15 / 29$ & $51 \cdot 7$ & $5 / 19$ & $26 \cdot 3$ \\
\hline Total & & 64 & $39 / 64$ & 61 & $27 / 59$ & 45 & $20 / 50$ & 40 & $6 / 28$ & $21 \cdot 5$ \\
\hline
\end{tabular}

TABLE VIA

PROPORTION OF PATIENTS WITH A POSITIVE D.A.T. IN EACH 2-YEAR PERIOD TO TOTAL NUMBER OF PATIENTS TESTED IN SERIES (142 CASES)

\begin{tabular}{|c|c|c|c|c|c|c|c|c|c|}
\hline \multirow{3}{*}{$\begin{array}{c}\text { First } \\
\text { Examined }\end{array}$} & \multirow{3}{*}{$\begin{array}{c}\text { No. } \\
\text { of } \\
\text { Cases }\end{array}$} & \multicolumn{8}{|c|}{ Years of Observation } \\
\hline & & \multicolumn{2}{|c|}{ 1st and 2 nd } & \multicolumn{2}{|c|}{$3 \mathrm{rd}$ and 4 th } & \multicolumn{2}{|c|}{ 5th and 6th } & \multicolumn{2}{|c|}{7 th and 8 th } \\
\hline & & No. & Per cent. & No. & Per cent. & No. & Per cent. & No. & Per cent. \\
\hline Early & 67 & $20 / 66$ & 32 & $7 ! 56$ & $12 \cdot 5$ & $5 / 48$ & $10 \cdot 4$ & $1 / 17$ & $5 \cdot 8$ \\
\hline Late & 75 & $19 / 75$ & $25 \cdot 2$ & $20 / 64$ & $31 \cdot 2$ & $15 / 50$ & 30 & $5 / 26$ & $19 \cdot 3$ \\
\hline Total & 142 & $39 / 141$ & $27 \cdot 6$ & $27 / 120$ & $22 \cdot 3$ & $20 / 98$ & 22 & $6 / 43$ & 14 \\
\hline
\end{tabular}


Correlation of D.A.T. with Disease Activity.Table VII compares disease activity and changes in D.A.T. during the observation period in three groups: Group I "negative", Group II "doubtful”, and Group III "more positive". Each group is subdivided into early and late cases, but this subdivision shows little relevance.

The same proportion of sero-positive and seronegative patients show activity which subsides, but a higher proportion of sero-positive patients remain active throughout their period of observation. None of the patients with a positive D.A.T. at some time were inactive throughout the observation period. Since those remaining active were followed for a slightly shorter period (mean $5 \cdot 3$ yrs) than those who became inactive (mean $5.7 \mathrm{yrs}$ ), it is reasonable to expect that the former group would eventually become inactive given more time.

Of the 64 patients who had a positive D.A.T. at some time, 35 had negative results in the first year and became positive later; 29 were positive at some time in the first year of observation and became negative later. Of the 35 cases in which the D.A.T.s were at first negative and later became positive, eleven were seen within the first year of their illness ("early") and information on the duration of "negativity" is therefore available. This averaged nearly 4 years (Table VIII) with a range from 2 to 7 years, nearly equal numbers changing over in each of the three age groups (0-9, 10-16, and 17-20). Ten out of eleven patients had active disease when the first D.A.T. (negative) was done and five out of eleven patients had active disease when the D.A.T. became positive.

The D.A.T. became negative between 0 and 8 years of age in three cases, between 9 and 16 years in eight cases, and between 17 and 20 years in three cases. All fourteen patients had active disease when the first D.A.T. (positive) was done and five of them still had active disease when the D.A.T. became negative. The mean duration of "positivity" in these fourteen cases was $2 \cdot 3$ years.

Table VIII and Table IX (overleaf) show that as many patients became negative as became positive in the older groups. These Tables also show that there is no strict correlation between D.A.T. "positivity" and disease activity. When the D.A.T. is negative, this is not unexpected, since a large number of patients had negative D.A.T.s throughout, despite disease activity at some time in 69 out of 78 cases.

TABLE VII

CORRELATION OF D.A.T. WITH DISEASE ACTIVITY

\begin{tabular}{|c|c|c|c|c|c|c|c|c|c|c|c|}
\hline \multirow{3}{*}{ Group } & \multirow{3}{*}{$\begin{array}{l}\text { No. of } \\
\text { Cases }\end{array}$} & \multirow{3}{*}{$\begin{array}{l}\text { Results of D.A.T. } \\
\text { during Observation }\end{array}$} & \multirow{3}{*}{$\begin{array}{c}\text { First } \\
\text { Examined }\end{array}$} & \multicolumn{8}{|c|}{ Disease Activity } \\
\hline & & & & \multicolumn{2}{|c|}{$\begin{array}{c}\text { Inactive } \\
\text { Becoming Active }\end{array}$} & \multicolumn{2}{|c|}{$\begin{array}{c}\text { Inactive } \\
\text { Throughout }\end{array}$} & \multicolumn{2}{|c|}{$\begin{array}{c}\text { Active Becoming } \\
\text { Inactive }\end{array}$} & \multicolumn{2}{|c|}{$\begin{array}{c}\text { Active } \\
\text { Throughout }\end{array}$} \\
\hline & & & & No. & $\overline{\text { Percent. }}$ & No. & Per cent. & No. & Percent. & No. & Per cent. \\
\hline I & 78 & Negative & $\begin{array}{l}\text { Early } \\
\text { Late }\end{array}$ & $\left.\begin{array}{l}3 \\
3\end{array}\right\} 6$ & $7 \cdot 7$ & $\left.\begin{array}{l}6 \\
3\end{array}\right\} 9$ & $11 \cdot 5$ & $\begin{array}{l}29 \\
19\end{array} 48$ & $61 \cdot 5$ & $\left.\begin{array}{r}1 \\
14\end{array}\right) 15$ & $19 \cdot 2$ \\
\hline II & 36 & Only One Positive & $\begin{array}{l}\text { Early } \\
\text { Late }\end{array}$ & 1) 2 & 6 & $\mathbf{0}$ & & $\left.\begin{array}{l}14 \\
13\end{array}\right\} 27$ & 75 & $\left.\begin{array}{l}3 \\
4\end{array}\right\} 7$ & 19 \\
\hline III & 28 & Two or More Positive & $\begin{array}{l}\text { Early } \\
\text { Late }\end{array}$ & $\left.\begin{array}{l}0 \\
1\end{array}\right\} 1$ & $3 \cdot 6$ & 0 & & 7) 15 & $53 \cdot 6$ & $\begin{array}{r}2 \\
10\} \\
12\end{array}$ & $42 \cdot 8$ \\
\hline Total & 142 & - & - & 9 & - & 9 & - & 90 & - & 34 & - \\
\hline
\end{tabular}

TABLE VIII

DURATION OF NEGATIVE RESPONSE IN ELEVEN "EARLY” CASES WHO CONVERTED TO POSITIVE LATER

\begin{tabular}{|c|c|c|c|c|}
\hline $\begin{array}{l}\text { Age at Onset when } \\
\text { D.A.T. was Negative } \\
\text { (yrs) }\end{array}$ & $\begin{array}{c}\text { Disease Activity } \\
\text { when First } \\
\text { Examined }\end{array}$ & $\begin{array}{c}\text { Age when D.A.T. } \\
\text { First Positive } \\
\text { (yrs) }\end{array}$ & $\begin{array}{c}\text { Disease Activity } \\
\text { when D.A.T. } \\
\text { First Positive }\end{array}$ & $\begin{array}{l}\text { Time Interval before } \\
\text { D.A.T. Positive for } \\
\text { First Time (yrs) }\end{array}$ \\
\hline $\begin{array}{r}1 \\
5 \\
5 \\
5 \\
5 \\
6 \\
8 \\
9 \\
12 \\
14 \\
15\end{array}$ & $\begin{array}{l}- \\
+ \\
+ \\
+ \\
+ \\
+ \\
+ \\
+ \\
+ \\
+ \\
+\end{array}$ & $\begin{array}{r}3 \\
7 \\
9 \\
7 \\
12 \\
8 \\
11 \\
12 \\
18 \\
20 \\
19\end{array}$ & $\begin{array}{l} \pm \\
\pm \\
\pm \\
\pm \\
= \\
= \\
+ \\
+\end{array}$ & $\begin{array}{l}2 \\
2 \\
4 \\
2 \\
7 \\
2 \\
3 \\
3 \\
6 \\
6 \\
4\end{array}$ \\
\hline 11 & - & - & - & Mean 3.7 \\
\hline
\end{tabular}


TABLE IX

DURATION OF POSITIVE RESPONSE IN FOURTEEN "EARLY" CASES WHO CONVERTED TO NEGATIVE LATER

\begin{tabular}{|c|c|c|c|c|}
\hline $\begin{array}{l}\text { Age at Onset when } \\
\text { D.A.T. was Positive } \\
\text { (yrs) }\end{array}$ & $\begin{array}{l}\text { Disease Activity } \\
\text { when First } \\
\text { Examined }\end{array}$ & $\begin{array}{l}\text { Age when D.A.T. was } \\
\text { First Negative } \\
\text { (yrs) }\end{array}$ & $\begin{array}{l}\text { Disease Activity } \\
\text { when D.A.T. was } \\
\text { First Negative }\end{array}$ & $\begin{array}{l}\text { Time Interval before } \\
\text { D.A.T. Negative for } \\
\text { First Time (yrs) }\end{array}$ \\
\hline $\begin{array}{r}1 \\
2 \\
6 \\
7 \\
9 \\
10 \\
11 \\
12 \\
12 \\
13 \\
14 \\
15 \\
15 \\
15\end{array}$ & $\begin{array}{l}+ \\
+ \\
+ \\
+ \\
+ \\
+ \\
+ \\
+ \\
+ \\
+ \\
+ \\
+ \\
+ \\
+\end{array}$ & $\begin{array}{r}3 \\
5 \\
8 \\
9 \\
11 \\
12 \\
15 \\
15 \\
14 \\
15 \\
16 \\
17 \\
18 \\
17\end{array}$ & $\begin{array}{l}\overline{-} \\
\overline{-} \\
\overline{+} \\
+ \\
\overline{-} \\
+ \\
\dot{+} \\
+ \\
+ \\
\overline{+} \\
-\end{array}$ & $\begin{array}{l}2 \\
3 \\
2 \\
2 \\
2 \\
2 \\
4 \\
3 \\
2 \\
2 \\
2 \\
2 \\
3 \\
2\end{array}$ \\
\hline 14 & & & & Mean $2 \cdot 3$ \\
\hline
\end{tabular}

Note: The remaining two "Early" cases out of the total 27 "Early" cases who had a positive D.A.T. at some time did not convert from positive to negative during their period of observation.
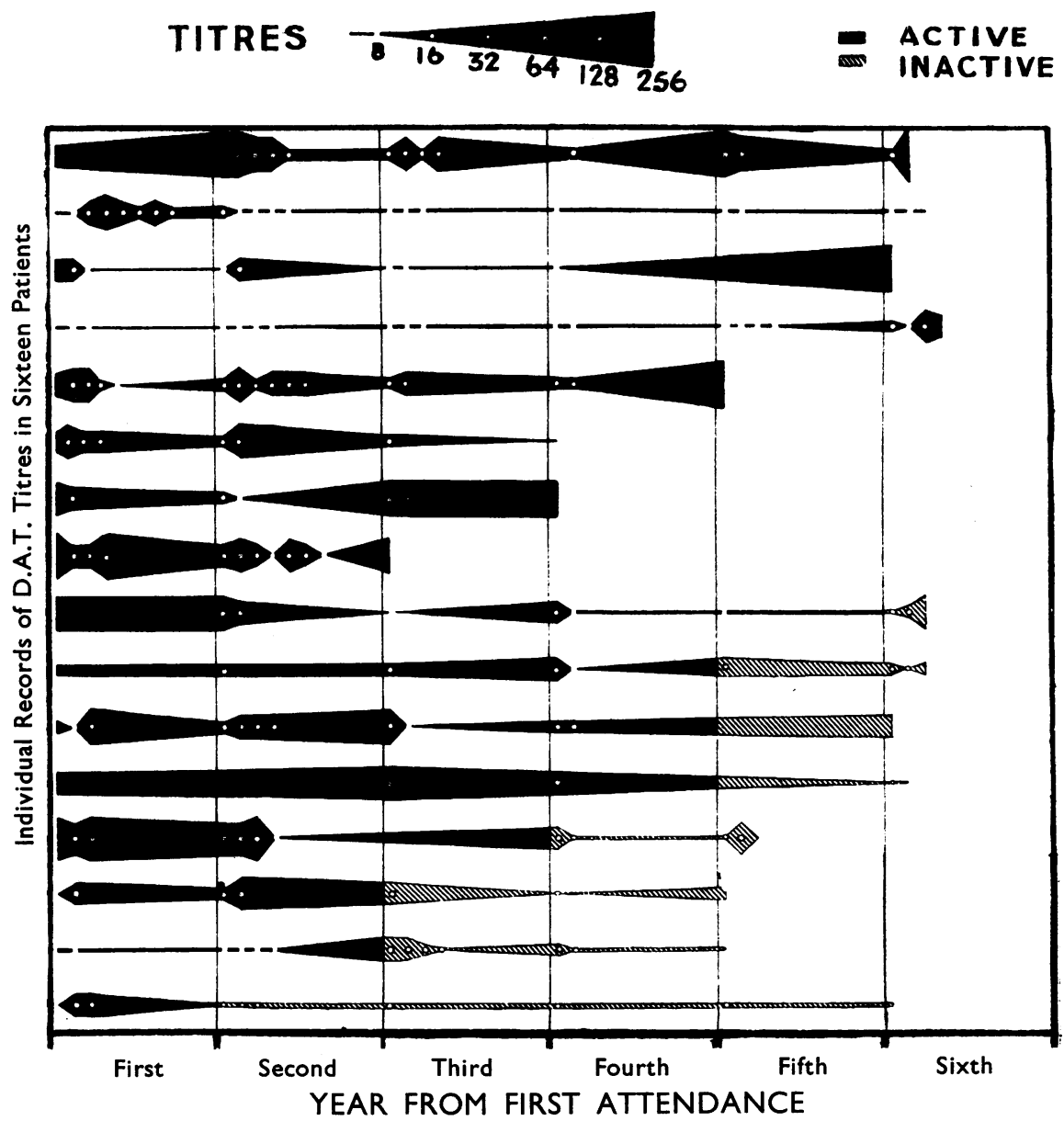

Figure.-Variation of titre in relation to disease activity in sixteen patients with Still's disease. 
The Figure shows the pattern of D.A.T. response in the sixteen patients who had two or more positive D.A.T.S at $1: 32$ or more. These patterns show that there is no particular trend in the behaviour of D.A.T. titres for individuals, and no two cases showed any similarity of pattern; this supports the statement made above that there is no strict correlation between D.A.T. positivity and disease activity. (The white dots in the Figure indicate the sequence of tests done, but are not related to the date when they were performed in each year.)

Although, as shown in Table III, serological positivity is more frequent in children whose disease starts in their 'teens, there seems to be little tendency for the group of children who are younger at the time of onset to convert to sero-positivity when they reach their 'teens. However, our period of observation is short and our numbers few. This is an important point which will be decided by further observation.

We have also tried to correlate the D.A.T. in these children with other clinical features, such as rash, nodules, erosions, lymphadenopathy, and splenomegaly (Table X). Although splenomegaly was found more commonly in the positive groups to a significant degree $(0.05>p>0.02)$, many comparisons are being made using the same data and a higher level of significance is needed.

If, however, we select the 28 highly positive cases (Group III: two or more positive D.A.T.s during observation) for comparison with the rest (Table XI), a greater probability emerges that nodules are related to D.A.T. positivity $(p=>0.001)$, as is known to be the case in adult rheumatoid arthritis (Ball, 1952).

\section{Summary}

142 patients suffering from Still's disease were followed for from 4 to 8 years; 13.4 per cent. had a positive D.A.T. (1:16 or more) at the first test, and 19.7 per cent. had two or more positive D.A.T.s. The mean number of D.A.T.s performed on each patient was $9 \cdot 5$.

Sero-positivity was more frequent in those patients who were older at the time of onset, but there was little tendency for those who were younger at onset to convert to sero-positivity when they reached their 'teens. Males tended to be more frequently seropositive than females.

TABLE $X$

CORRELATION OF D.A.T. WITH OTHER CLINICAL FEATURES

\begin{tabular}{|c|c|c|c|c|c|c|c|c|c|c|c|c|c|}
\hline \multirow{3}{*}{ Group } & \multirow{3}{*}{\multicolumn{2}{|c|}{$\begin{array}{l}\text { D.A.T. } \\
\text { Results }\end{array}$}} & \multirow{3}{*}{$\begin{array}{l}\text { Total } \\
\text { No. of } \\
\text { Cases }\end{array}$} & \multicolumn{10}{|c|}{ Clinical Features } \\
\hline & & & & \multicolumn{2}{|c|}{ Rash } & \multicolumn{2}{|c|}{ Nodules } & \multicolumn{2}{|c|}{ Splenomegaly } & \multicolumn{2}{|c|}{$\begin{array}{l}\text { Lymphadeno- } \\
\text { pathy }\end{array}$} & \multicolumn{2}{|c|}{ Erosions } \\
\hline & & & & No. & Percent. & No. & Percent. & No. & Percent. & No. & Percent. & No. & Percent. \\
\hline III & & $\begin{array}{c}\text { Two or More } \\
\text { Positive }\end{array}$ & 28 & 6 & 22 & 7 & 25 & 8 & 29 & 18 & 64 & 14 & 50 \\
\hline II & & One Only Positive & 36 & 10 & 28 & 0 & 0 & 13 & 36 & 14 & 39 & 12 & 33 \\
\hline 1 & & All Negative & 78 & 21 & 27 & 4 & 5 & 13 & 17 & 35 & 45 & 22 & 56 \\
\hline & Total & . & 142 & 37 & - & 11 & - & 34 & - & 77 & - & 48 & - \\
\hline
\end{tabular}

TABLE XI

CORRELATION OF D.A.T. WITH OTHER CLINICAL FEATURES

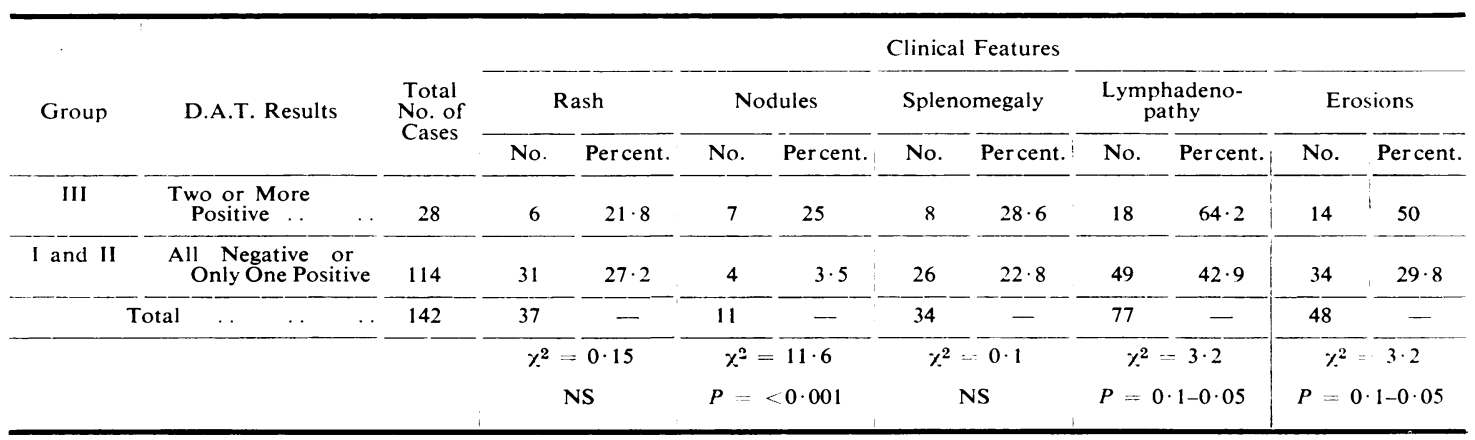


There was no typical pattern of D.A.T. response throughout the period of follow-up; there was no correlation with duration of disease and little correlation with disease activity.

An attempt was made to correlate the D.A.T. with other clinical features, such as rash, nodules, erosions, lymphadenopathy, and splenomegaly. When the highly-positive group (two or more positive D.A.T.s) was compared with the remainder, nodules appeared to be related to sero-positivity, as in adult patients.

\section{REFERENCES}

Ball, J. (1952). Ann. rheum. Dis., 11, 97.

Bywaters, E. G. L., and Scott, F. E. T. In "Recent Advances in Clinical Pathology," ed. S. C. Dyke. Unpublished.

Greenbury, C. L. (1957). Ass. clin. Path., Broadsheet No. 18.

Rose, H. M., Ragan, C., Pearce, E., and Lipman, M. O. (1948). Proc. Soc. exp. Biol. (N.Y.), 68, 1.

Scott, F. E. T. (1952). Lancet 1, 392 .

Titre d'agglutination différentielle (D.A.T.) dans l'arthrite rhumatismale juvénile

\section{RÉSUMÉ}

On observa 142 cas de maladie de Still pendant 4 à 8 ans; $13,4 \%$ de ces cas accusèrent un D.A.T. positif ( 1 : 16 ou plus) à la première détermination et $19,7 \%$ eurent deux ou plus titres positifs. En moyenne, le D.A.T. fut effectué 9,5 fois chez chaque malade.

La séro-positivité fut plus fréquente chez des enfants plus âgés au moment du début de la maladie, mais il n'y eut qu'une tendance faible chez des enfants à début précoce à devenir séro-positifs après avoir dépassé l'âge de 10 ans. Les garçons tendaient à être séropositifs plus souvent que les filles.

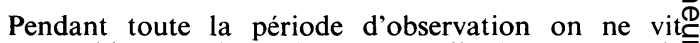
aucun tableau typique de D.T.A.; il n'y eut pas de 3 corrélation avec la durée de la maladie et peu de cor- $\square$ rélation avec son évolution.

On essaya de mettre en corrélation le D.A.T. et lesautres caractères cliniques, tels que nodules, exanthème, érosions, lymphadenopathie et splénomégalie. En com=parant le groupe fortement positif (deux ou plus D.A.T positifs) avec le reste, on trouva, comme chez des adultes, une plus grande fréquence des nodules dans ce groupe.

Cifra de aglutinación diferencial (D.A.T.) en la artritis̆ reumatoide juvenil

SUMARIO

Se observaron 142 casos de enfermedad de Stil $\square$ durante 4 a 8 años; en un $13.4 \%$ ellos la réaction dew aglutinación diferencial fué positiva (1:16 o más) en la primera determinación y en un $19,7 \%$ se obtuvo dos o más reacciones positivas. En promedio se procedió a 9,5 determinaciones de la D.A.T. en cada enfermo.

La sero-positividad fué más frecuente en niños dệ mayor edad al tiempo del comienzo de la enfermedad No pero niños enfermos desde la edad más tierna tuvieronor poca tendencia a convertirse en sero-positivos despuéso de rebasar la edad de 10 años. Los chicos tendían a presentar reacciones sero-positivas más frecuentemente $\vec{\circlearrowleft}$ que las chicas.

Durante el entero período de observación no sē dibujó ningún cuadro típico de la D.A.T.; tampoco se observó correlación alguna con la duración de la enfermedad, ni mucha con su evolución.

Se tentó correlacionar la D.A.T. con otros rasgos clínicos, como exantema, nódulos, erosiones, linfade patía y esplenomegalía. Al comparar el grupo fuerfemente positivo (dos o más D.A.T. positivas) con demás, se vió, como en enfermos adultos, una relac节 entre nódulos y sero-positividad. 